\title{
Sustainability Implications of the Evolution of Rice Farming amid Rural Poverty: The Case of the Chhotanagpur Plateau in Eastern India
}

\author{
Pabitra Banik $^{1}$, Christopher Edmonds ${ }^{2} \&$ Nobuhiko Fuwa $^{3}$ \\ ${ }^{1}$ Agricultural and Ecological Research Unit, Indian Statistical Institute, Kolkata, India \\ ${ }^{2}$ Asian Development Bank, Metro Manila, Philippines \\ ${ }^{3}$ Graduate School of Asia-Pacific Studies, Waseda University, Tokyo, Japan \\ Correspondence: Nobuhiko Fuwa, Graduate School of Asia-Pacific Studies, Waseda University, Nishi-Waseda \\ Bldg.7F, 1-21-1 Nishi-Waseda, Shinjyuku-ku, Tokyo 169-0051, Japan. Tel: 81-3-5286-3919. E-mail: \\ nfuwa@waseda.jp
}

Received: April 25, 2014 Accepted: May 27, 2014 Online Published: July 31, 2014

doi:10.5539/jsd.v7n4p282 URL: http://dx.doi.org/10.5539/jsd.v7n4p282

\begin{abstract}
This paper analyses longitudinal household surveys from Purulia and Giridih, two adjacent districts on the Chhotanagpur Plateau in Eastern India in 1997 and 2006, to assess the sustainability of the evolving local rice-based agricultural system. Increasing population with little outmigration suggests mounting burden on the already fragile land endowment. The pattern of land sales and purchases suggests land consolidation among fewer farmers is not a concern. Use of high yielding varieties (HYVs) and of chemical inputs increased in both districts. However, rice yields have increased in Purulia but stagnated in Giridih. Socioeconomic progress is more apparent in Purulia in other aspects as well, such as its land reform policy, the Panchayat system and higher rate of HYV adoption. Sustainability of the agricultural system in Purulia may be less than in Giridih due to its pattern of land transactions and the cautious move among farmers toward high-chemical intensity agriculture.
\end{abstract}

Keywords: agricultural sustainability, rain-fed rice agriculture, on farm, farm household, landholdings, fertiliser use

\section{Introduction}

As is typical in rainfed lowland rice areas in Asia, the Chhotanagpur Plateau in India constitutes an area of low agricultural productivity where large numbers of household suffer from severe poverty. The incidence of poverty among households in the relatively remote area covered in the study reported on in this research is among the highest in India. Practice of subsistence farming in the unfavourable and risky environmental area remains the common basis of livelihoods. The natural resource base can be characterized as being poorly suited to agriculture due to climatic, water resource and soil conditions; and many decades of environmentally damaging agricultural practices and highly erosive monsoon rains, deforestation and accelerated soil erosion have left many parts of the plateau severely degraded (Banik et al., 1994).

Increasingly, families that live and work in the area depend upon non-agricultural income generating activities to sustain their households - especially during the post-Monsoon season. The majority of these non-farming activities involve low productive and low paying work in home based microenterprises, handicrafts and casual employment. Trends with respect to the state of natural resources, combined with the paucity of options for high-return non-agricultural employment, make challenging future economic prospects for the area and the households that derive their livelihoods in this challenging environment. Accordingly, studying the area provides an ideal site for understanding long-term developments in a relatively remote and poor region of Eastern India at a micro-level.

The paper addresses three main questions related to these themes: (i) how have rice yields in our rain-fed rice study area in Eastern India changed over time, (ii) how have the inputs to rain-fed rice agriculture changed over time in the area and (iii) what implications have changes in rain-fed rice cultivation practices in the area had for the environmental (and economic) sustainability of the agricultural system? 
In this study, a longitudinal household survey was conducted in an effort to understand the main biophysical and socioeconomic factors driving farmers' livelihood strategies and use of the resources available to them in adjacent Districts (Giridih and Purulia) of the states of Bihar (located in the newly formed Jharkhand State) and West Bengal. (Note 1) This paper is based on the results from the first two rounds of surveys initiated in 1997 and 2005, and focuses on the potential implications for the sustainability of the livelihoods of poor households in the area as a result of the changes in rice-farming practices and land tenure during the period.

The next section provides a brief review of some of the most relevant literature pertaining to agricultural change and the sustainability of the agricultural system in rainfed rice growing areas of India. The paper then briefly describes the environmental and historical characteristics in the area studied in this paper, and outlines the dataset used in the analysis. Subsequent sections describe salient developments in rice farming in the area during 1997-2005. Section 4 provides a brief description of changes in landholdings. The rest of the paper considers changes in rice farming in the area, progress in the adoption of high yielding rice varieties (HYVs), changes in the use of inputs for rice production and changes in rice yields. The paper concludes by summarizing its findings regarding the sustainability of the faming system and local economy in the study area.

\section{Sustainability of Rainfed Rice Agriculture in India: A Literature Review}

A number of existing studies have examined long term changes in rice yields and rice inputs, and the implications of the observed changes on the agricultural sustainability of rain fed rice cultivation in Eastern India An even larger body of existing research has considered these questions in other parts of India and agro-climatically similar areas further afield.

Ghosh (2010) and Kumar and Mittal (2006) examined agricultural productivity trends and estimated rates of growth of output and total factor productivity in Eastern India. Examining farm data from West Bengal, Ghosh (2010) estimated that rice output grew at a rate of 1.2 per cent per annum in the period 1980 to 1992, reversing falls in output observed during the 1970s. This growth rate was shown to be statistically significant, primarily due to yield growth ( 0.72 per cent per annum in the 70 s to 4.07 per cent per annum in 1980-81 to 1991-92). The same study found that total rice production and yield growth declined significantly from 1992 to 2005 (yield growth declined to 1.61 per cent per annum during this period).

A study of the carrying capacity of rain-fed agriculture in India (Venkateswarlu \& Prasad, 2012) concluded that there was room to increase food grain production on these lands - particularly in Eastern India - through the adoption of improved practices on resource conservation, more efficient use of rainwater, soil fertility improvement and better technology transfer. While significant production growth of major rain-fed crops was achieved during the years 1998 to 2009 , there was a persistent yield gap between rain fed and irrigated areas. For instance, average yield of rain-fed rice is about 1 ton while achievable yield is up to $2,500 \mathrm{~kg} / \mathrm{ha}$. With almost 60 per cent of total area cultivated to rice taking place on rain-fed areas, constraints to close this yield gap must be urgently addressed.

Other studies examining rain-fed regions in Eastern India have looked at the adoption of modern varieties and its corresponding impact on agricultural productivity. The rainfed region of Eastern India was estimated to be important in driving overall trends toward MV adoption, accounting for nearly a third of total MV adoption (Janaiah et al., 2006) in Assam, Bihar, Madhya Pradesh and West Bengal. The study covered the states of Assam, Bihar, Madhya Pradesh and West Bengal, and found that each area experienced significant jumps in rice yields during the 1980s. Yield increases ranged from 3.45 per cent in Madhya Pradesh to 6.2 per cent in West Bengal. By 1998-2000, the study found that the adoption rate in Eastern India had reached nearly 80 per cent of total rice area. Nonetheless, average yields remained low in the area compared to the rest of India due to its unfavourable environment. The study also found that about one-third of MV area in Eastern India used MVs developed for other regions. MV adoption in Eastern India proceeded more quickly in the late 1980s, when shallow and tube well irrigation facilities were expanded within the region. Increased MV adoption in Eastern India was accompanied by increased use of chemical fertilizers.

To test the productivity implications of MV adoption and their hypothesis that adoption of improved MVs has reduced production risks over time, the authors estimated an instability index based on farm-level yields for two periods (early Green Revolution (GR) years 1971-85 and post Green Revolution period 1986-2000). Estimates suggested that instability in rain-fed states of Bihar and West Bengal declined but remained at higher levels than in irrigated states of Punjab and Andhra Pradesh.

These studies suggest that while productivity growth exhibited a declining trend starting from the 1990s, the observed levels of yield and input use did not raise sustainability concerns. The studies found TFP growth was positive and there was common technology and knowledge transfer, and investments in research and extension 
should push the productivity frontier (Kumar \& Mittal, 2006; Venkateswarlu \& Prasad, 2012).

Sharma and Shardendu (2011) constructed an Agricultural Sustainability Index (ASI) for 150 farms over the periods 1950-1960, 1980-1990 and 2000-2010 using both primary and secondary data from Gangapur village in Bihar state. They selected a total of 30 variables (social, economic and ecological) to construct their sustainability index, based on the variables significance to the locality, availability of data and availability of threshold values for each variable. They observed that economic sustainability (i.e. food grain yield/ha, fertilizer use/ha, percentage of arable land devoted to various cropping cycles, other access to finance- and market-related variables) increased over the years covered in their research. Observed changes in food grain yield $(2,4 \mathrm{~kg} / \mathrm{ha}$ in $2000-2010)$ and fertilizer use $(360.6 \mathrm{~kg} / \mathrm{ha}$ in 2000-2010) were way below estimated thresholds for the area $(12,770 \mathrm{~kg} / \mathrm{ha}$ for yield and $1,070.89 \mathrm{~kg} / \mathrm{ha}$ for fertilizer use). However, ecological sustainability declined (i.e. gene pool erosion of native crops, a reduction in topsoil depth, a decline in level of water table, reduced use of eco-friendly practices, declining ecological literacy). Nevertheless, changes in ASI values observed over the three decades were statistically insignificant, suggesting that agricultural practices have maintained broadly sustainability in this part of rural Eastern India in recent decades. The authors predict that this is likely to continue.

Expanding our review to consider studies focusing on areas outside of Eastern India, we find that studies conducted on predominantly irrigated lands in northern Indian states, which border Eastern India and share some of its characteristics, have produced similar findings (Singh, 2000; Kumar \& Chand, 2012). In a village-level study in Uttar Pradesh, rice production systems were studied in the flood-prone village Ecauna and flood-free village Tewari-ka-Tarkulawa (Ballabh \& Pandey, 1999). In Ecauna, area under rice cultivation expanded only by 8 percentage points, from 20 per cent in 1982 to 28 per cent in 1996. This expansion was due to increased adoption of local varieties; HYV adoption was constant during the period under study. The yield of local varieties increased from 7-9 qt/ha (1981-82) to 12-16 qt/ha (1995-96). HYV yield rose to 30-40 qt/ha in 1995-96 from 12-15 qt/ha in 1981-82. Input use for HYV rice rose from 35-40 kg/ha (1981-82) to 50-70 kh/ha (1995-96). In Tewari-ka-Tarkulawa on the other hand, HYV adoption expanded, replacing almost the entire rice area under local varieties. The yield of HYVs increased from 25-30 qt/ha (1981-82) to 35-40 qt/ha (1995-96). Input use for HYV rose from 50-60 kg/ha (1981-82) to 100-120 kh/ha (1995-96). Farmers also reported adding on average, $28-35 \mathrm{~kg} / \mathrm{ha}$ of phosphorus in cultivating HYVs.

Intensive use of agro-chemicals was observed in Haryana, where fertilizer consumption increased from 3 to 130 $\mathrm{kg}$ ha-1 during the period 1960-61 to 1991-92 (Singh, 2000). For rice, fertilizer consumption was $160 \mathrm{~kg}$ ha-1. By the end of the study period, yield per hectare reached $1.37 \mathrm{Mgha}-1$ from $0.63 \mathrm{Mgha}-1$ in $1965-66$. Several environmental problems were linked to these changes in yield and input-use trends, including decline of ground water table and soil fertility changes. Water table decline in rice-wheat growing districts of Haryana ranged from 3-10 meters. Time series data $(1967-68,1977-78,2006-07)$ in Karnal district in Haryana showed marked change in the area's cropping pattern. Wheat, fodder, rice and maize were predominant in 1967-68, which evolved to wheat-rice-fodder in 1977-78 and finally to primarily wheat-rice in 2006-07. Sustainability of the rice-wheat system is a major concern due to depletion of ground water resources associated with this cropping system and unavailability of further land for cultivation. The researchers suggest that to arrest the unsustainability of agriculture production, diversification of cropping system is paramount (Kumar \& Chand, 2012). Review of the findings from studies most closely related to the questions being asked in the research being reported in this paper indicates that the few studies that have focused on rain-fed rice-based agriculture in Eastern India have found that yields have increased through the adoption of modern varieties and associated Green Revolution technology (especially increased use of chemical fertilizer), but increases have lagged behind those found in other parts of India, which suggests there is still potential for rice production and yields to increase from the region. The single study identified that assessed the sustainability implications of applying these new technologies in such environments found no significant declines in sustainability with the adoption of new technologies. However, the scant number of studies and the fairly limited methods used in them make clear that there is a need for more research in this area.

The next section of this paper briefly describes the environmental and historical characteristics in the area studied in this paper and outlined the dataset used in the analysis. Subsequent sections describe salient developments in rice farming in the area during 1997-2005. Section 3 provides a brief description of changes in landholdings. The rest of the paper considers changes in rice farming in the area, progress in the adoption of high yielding rice varieties (HYVs), changes in the use of inputs for rice production and changes in rice yields. The paper concludes by summarizing its findings regarding the sustainability of the faming system and local economy in the study area. 


\section{Description of the Study Area}

The data analyzed in this paper comes from panel household survey conducted in 16 villages equally in two Districts (Giridih \& Purulia) in adjacent Eastern Indian states of Jharkhand (formerly part of Bihar) and West Bengal (1996-97 and 2004-06). Both districts are located within the Chhotanagpur Plateau and share similar biophysical characteristics (e.g., common topographical features, rainfall and land use patterns), but dissimilar institutions of local governance. In Purulia District (West Bengal) the Panchayat system of local governance is well developed and land reform has been actively implemented. In contrast, in Giridih District (Jharkhand) the Panchayat system is less effective and functions to a lesser degree as large landholders exercise considerable influence over local economic and political affairs.

Physiographically, the study area is located at the eastern fringe of the Chhotanagpur plateau, located in the southwestern corner of the eastern Ganges Plain (see Figure 1). Prior to the British Colonial era (starting in the late 1850 's), the area was largely unsettled and densely forested. Oral history and the limited documentation available suggest that the area's small population subsisted from the extraction of local forest products. The population reportedly carried out very little settled agricultural activity, which was focused on cultivation of local rice, pulses, millets and vegetables (Sen et al., 1984). With colonization, the area became an important source of timber used in the construction of national railways. This resulted in extensive deforestation. Also, during this period, the area was opened up to settlers to farm on the cleared lands, and marginalized tribes appeared to have had particular interest in moving into the relatively unsettled area. Although records are scarce, it seems most immigrants into the area came from other parts of Eastern India.

Topography map for Bihar and West Bengal

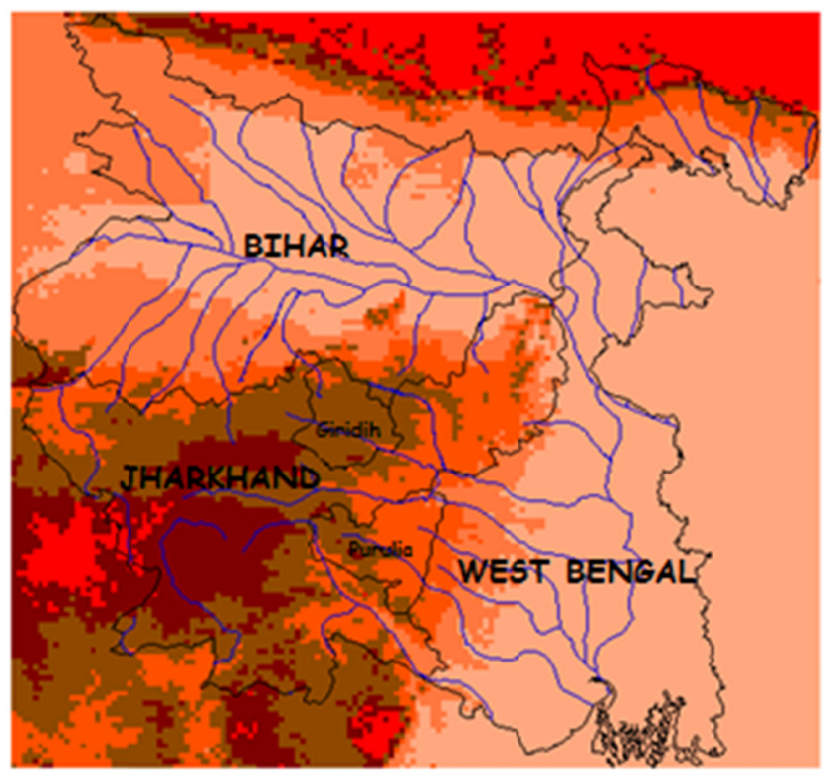

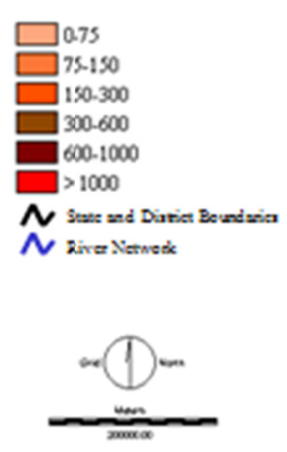

notce DEM cutrosted fron rwing

Figure 1. Location and topography of Giridih and Purulia districts in eastern India

With independence, central government-led initiatives established state-owned mining industries in Giridih District, which was rich in mineral resources (particularly mica and coal) as part of a broader development strategy seeking to promote development. As the mining industry flourished for about thirty years, attracting more immigrants, until a less costly artificial substitute for mica was invented and other mineral resources became depleted. With the decline of the mining industry, many of the former immigrants - having settled in the area for multiple generations - turned to subsistence agriculture for their livelihoods.

The history of Purulia district of West Bengal differs markedly from that of Giridih, as the area has served as buffer zone between the Damodar plains and Bihar plateau for centuries. When the area came under British rule, local Zamindars (landholding elites, who held large tracts of land and exercised dominion over landless tenant famers) had governing authority over natural resources, including forests resources, exercising control over the 
local economy through land leases and rental charges. Except in a few coal areas, no important industries flourished in the area despite modest efforts to encourage industry to operate in the area.

In recent decades, agriculture has become the predominant basis of livelihoods of residents in the districts. The main crops cultivated in the two districts are similar. Households from scheduled tribe backgrounds form a significant part of the population in both districts. Post-independence government reforms, particularly introduction of the Panchayat system and a major land reform carried out during the $1980 \mathrm{~s}$, increased the number of small landowners in Purulia and had major impacts on Purulia District's economy. It has altered land use and the technology applied in agriculture in the area. Local Panchayats have worked with agricultural extension agents and agricultural input suppliers to distribute High Yielding Varieties (HYVs) of rice seed, and modern inputs like fertilizer, pesticides, other agrochemicals were distributed to farmers.

The selection of villages and households within the villages from the two districts included in the study applied stratified random sampling. First, four blocks distributed throughout from each district were selected, then two villages from each block were selected to ensure one village had relatively easier access to main transport routes and markets while the other was more remote (Figure 2). Approximately 30 to 40 households were selected randomly for inclusion in the survey from the list of village residents using stratified random sampling based on household landholding (i.e., large $>25$ acres, medium -12 to 25 acres, small 6 to 12 acres, marginal 0.5 to 6 acres and landless or virtually landless $<0.2$ acres), with weights from each landholding category assigned in rough proportion to the landholding size class's representation in the total village population according to the most up to date Census available at that time. 

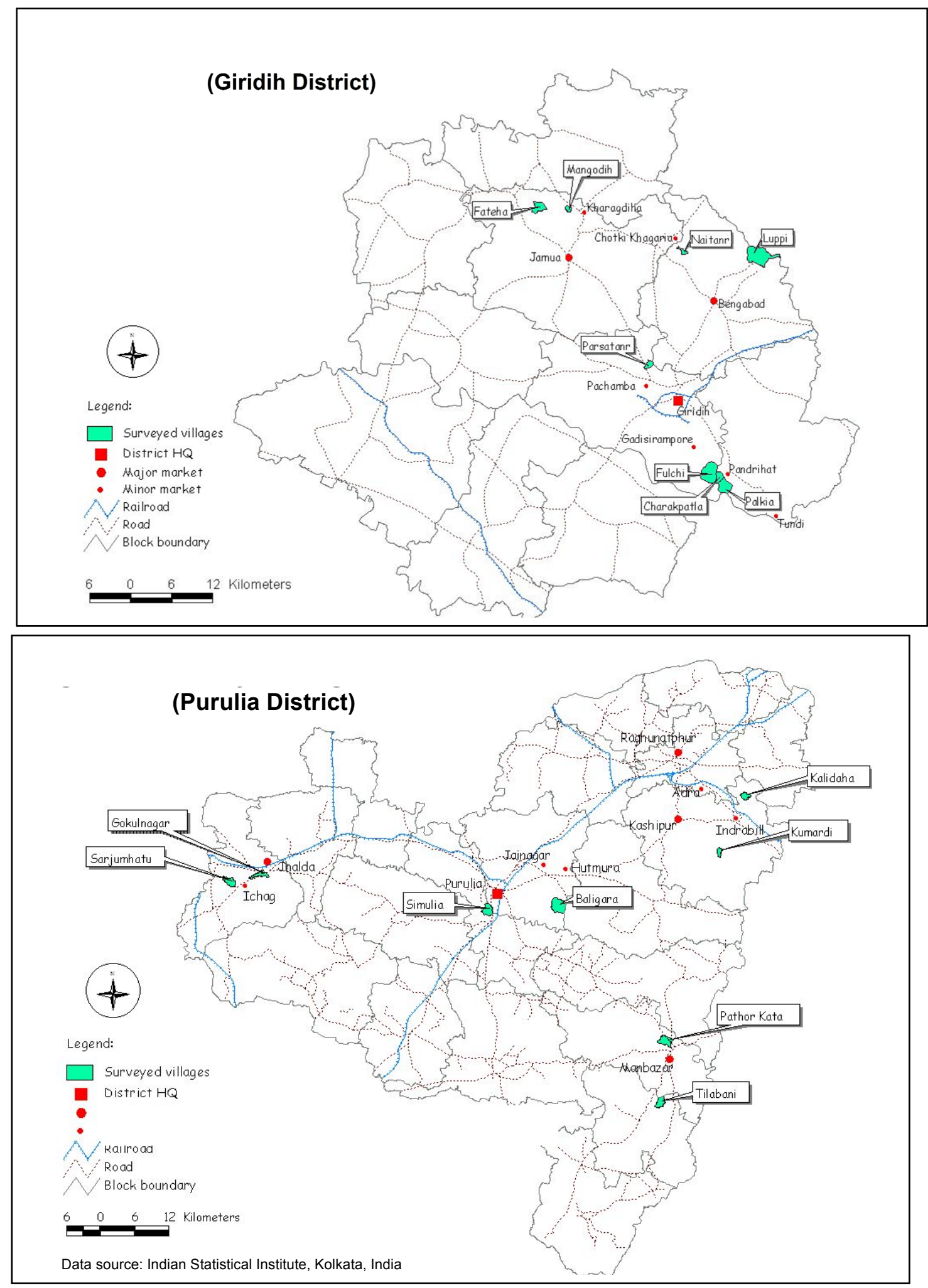

Figure 2. Surveyed villages, transport routes and main urban settlements in Giridih and Purulia districts

The panel data collected for the study tracks the agricultural and economic activities of nearly 600 households over a period that spans nearly a decade (see Table 1). However, over time, as a result of household divisions, the number of households surveyed increased substantially, rising from 266 to 330 between 1997 and 2004 in Giridih, and from 275 to 348 (increases of roughly 24 per cent and 27 per cent in Giridih and Purulia districts, 
respectively) between 1998 and 2006 in Purulia. (Note 2) Attrition from the survey sample was quite low, with only 12 households (divided equally across Giridih and Purulia) of the original 541 households being dropped from the follow up survey due to the death or migration of all household members. Total population among surveyed households increased by a quarter and combined with the low rate of outmigration, suggests there is mounting population pressure in the area that places additional pressure on the land endowment on the ecosystem of this fragile area.

Table 1. Household survey sample

\begin{tabular}{ccccccc}
\hline District & $\begin{array}{c}\text { Number of households interviewed } \\
1997 / 1998\end{array}$ & $2004 / 2006$ & attrition & rate & $\begin{array}{c}\text { attrition } \\
\text { households }\end{array}$ & $\begin{array}{c}\text { Number of divided } \\
\text { Pct. change in the number of } \\
\text { households }\end{array}$ \\
\hline Giridih & 266 & 330 & 6 & $2.3 \%$ & 70 & $24.1 \%$ \\
\hline Purulia & 275 & 348 & 6 & $2.2 \%$ & 79 & $26.6 \%$ \\
\hline Total & 541 & 678 & 12 & $2.2 \%$ & 149 & $25.3 \%$ \\
\hline
\end{tabular}

Source: authors' calculation based on the household survey data collected in Giridih and Purulia. See text for details.

In rural area of developing countries with large agricultural sectors, household income typically correlates strongly with size of landholding. The survey collected information on household demographic characteristics, agricultural inputs and outputs (at the plot-level), allocation of agricultural output (e.g., how much output was consumed by the household and how much sold), and household capital and livestock holdings. The baseline survey was conducted in 1997 in Giridih and in 1998 in Purulia, and a second round (follow-up) survey was conducted in 2004 in Giridih and in 2006 in Purulia.

Living standards in the study area are low. According to official government poverty estimates, the incidence of poverty in our study area was among the highest in the country. Statewide headcount poverty ratios in Bihar and West Bengal were the second and third highest in 1987-88, first and fifth highest in 1993-94, and second and fifth highest in 1999, respectively (Deaton 2001). Indicators such as estimated household income per capita, the value of asset/wealth holding, and access to public services like education and potable water suggest standards of living in the study area are low. Across the 16 sampled villages, the estimated average annual household gross income was Rs. 27,269 (equivalent to about $\$ 680$ at the exchange rate prevailing at the time of the survey) and average per capita annual gross income was only Rs. 4,018 (about \$100) in the baseline survey. The planning commission's official poverty line in 1999 (Deaton 2001) and the estimated per capita gross income indicated that $60 \%$ of the sampled households were poor.

Given the low living standards, it is unsurprising that food security appears to be the primary objective of surveyed farms - resulting in a strong orientation toward subsistence in production. Past episodes of hunger and malnutrition recounted by suvyed households would explain the fixation on satisfying food security in the orientation of agriuclutual activity. Change in this orientation has come slowly as well, with the follow up suvey showing only a modest increase in the share of households selling rice. The sale of farm outputs provided only $3 \%$ of the total household gross income, on average, whereas the imputed value of home-consumed farm outputs equaled $34 \%$ of the total household gross income in the baseline survey. Challenges with respect to the comparability of imputed income estimates between the baedline and follow up surveys make it difficult to strictly compare these figures across the two surveys.

Diversification of household income sources is a prevalent strategy for coping with risk and vulnerability in rural areas with less favorable economic and agroclimatic conditions. Considering the primary occupation of working age household members reported in the baseline survey in Purulia survey, the most common occupation was "unpaid family labor on family farm," which was reported by $50 \%$ of the total individuals across the surveyed households that reported having a principal occupation. Other common principal occupations were miner (20\%), followed by casual day laborer (10\%) and paid full-time or part-time agricultural laborer (4\%). In the off season, household labor is generally idle, engaged in temporary agriucultural jobs in neighboring areas, or migrates to seasonal work in agriculture or constructions. Households also engage in a variety of home-based craft production such as jute weaving, pottery making, and production of leaf plates.

Indicators of the level of education such as the literacy rate or the average years of schooling were slightly higher 
in Purulia (35\% literacy rate and 3.9 years of schooling) than in Giridih (20\% literacy rate and 3.4 years of schooling) at the time of the baseline. Furthermore, average educational attainment appears to have risen more rapidly in Purulia in recent years than in Giridih. Evidence of gender discrimination (e.g., differences in wage rates commanded by male and female workers) suggests that this discrimination was more pronounced in Giridih than in Purulia. There was a higher share of female-headed households among the surveyed families in Purulia than in Giridih.

Households displayed low levels of savings, reflecting both their low income and economic vulnerability. The principal form of savings is livestock holding, but cows and bullocks serve a additional functions in draft power for agriculture and dairy production. The average value of livestock holdings was roughly Rs 8,000 per household at the time of baseline survey. Nearly two-thirds of surveyed households reported owning one or more bullocks, while rates of ownership of smaller farm animals such as goats and poultry was lower. Holdings of physical assets, including agricultural tools and machinery, household appliances, and transport equipment were limited to an average value per household of only Rs 3,000 (equivalent to about $\$ 76$ at the time the survey was conducted). One quarter of sampled households reported owning no appliances and most (75\%) indicated their main means of transport was a bicycle.

Surveyed households with scheduled caste (SC) and scheduled tribe (ST) backgrounds generally had lower income and capital holdings, and had a higher poverty incidence than other households. Villages in which scheduled tribe families predominated tended to be more distant from a source of drinking water, roads, and other public facilities - although the number of villages in the sample is small. In villages with households from diverse caste/ethnic backgrounds, residential segregation was observed, with scheduled caste and scheduled tribe families holding less favourable quality. Although Giridih and Purulia districts share similar agroecological characteristics, the political systems and governing institutions in the two states differ markedly. West Bengal State came under the Left Front government in 1976, which subsequently implemented a major land reform program. The land reform placed an area ceiling on legally permissible landholdings, redistributed land to the landless, and conferred secure tenancy rights. This was accompanied by the implementation of a system for democratic local governance, the panchayat, at the village level. Bihar State, in contrast, underwent no serious land reform and the panchayat system has not been vigorously implemented there. In Bihar, large landholders tend to exercise considerable influence over economic and political institutions down to the village level. Given the contrasting histories and resulting differences in institutional environments, we might expect some systematic differences in the socioeconomic outcomes (e.g., level of poverty, agricultural practices, etc.) between the two districts.

\section{Empirical Findings and Discussinos}

\subsection{Changes in Land Holdings-Incidence of Land Purchases and Sales}

The long period between the baseline and follow up surveys in our panel allow sufficient time to gauge changes in land ownership and landholding among surveyed households. Our data suggest that land markets were active among households in all but one of the villages in our sample. Fifteen of the sixteen villages surveys reported changes in landownership during the years covered by the panel. However, the changes nearly always involved transfers of only small plots so do not presage significant changes in land use or the local agricultural system.

Land markets were more active in Giridih than in Purulia according to our survey results. In Giridih, 34 per cent of the respondent households reported having engaged in the purchase or sale of land (17 households had both transactions). This compared to 10 per cent of the respondent households in Purulia (with only 2 households reported having both bought and sold land). In addition to having a higher frequency of land transactions, the total land area involved in the transactions was also larger in Giridih than in Purulia during the period between 1997 and 2005 (the years the baseline survey began and follow up survey was completed). Overall, 61 acres changed ownership in Giridih among surveyed households. The land purchased (44 acres) exceeded the area sold (17 acres). This compared to a total of 16 acres sold and 5 acres purchased among surveyed households in Purulia district. Nearly 18 per cent of the respondent households (58 households) reported land sales in Giridih district, while only 6 per cent of the respondent households ( 22 households) reported land sales in Purulia. Full details on the land market transactions reported by respondent households are reported in Tables 2 and 3. 
Table 2. Land area purchased by district

\begin{tabular}{lccc}
\hline District & Total area purchased (acres) & Number of plots purchased & Average area per plot purchased (acres) \\
\hline Giridih & 44.41 & 88 & 0.50 \\
Purulia & 5.30 & 11 & 0.48 \\
\hline
\end{tabular}

Source: authors' calculation based on the household survey data collected in Giridih and Purulia. See text for details.

Table 3. Land area sold by district (acres)

\begin{tabular}{cccc}
\hline District & total area sold (acres) & number of plots sold & average area per plot sold (acres) \\
\hline Giridih & 17.19 & 74 & 0.23 \\
Purulia & 16.09 & 30 & 0.54 \\
\hline
\end{tabular}

Source: authors' calculation based on the household survey data collected in Giridih and Purulia. See text for details.

The most common reason given for land sales was for marriage in both districts, suggesting the practice of dowry is still common in both districts. Sale of land to provide a dowry was the stated impetus for 62 per cent of total transactions in Giridih and 50 per cent in Purulia. Other reasons given for selling land included: medical (14 per cent in Giridih and 23 per cent in Purulia), other 'crisis' ( 9 per cent in Giridih and 23 per cent in Purulia) and to cover education and business expenses (about 4 per cent in Giridih). Table 4 summarizes reasons respondents gave for reported land sales.

In regards to motives for land purchases, 22 per cent of the respondent households ( 72 households total) in Giridih and 3 per cent of the respondent households (11 households) in Purulia, reported having purchased land at some point between the baseline and follow up surveys. In most cases, the source of funds for land purchases came from non-agricultural incomes rather than crop incomes. Fully 92 per cent of land purchases in Giridih relied on this source of financing while 82 per cent of land purchases in Purulia did so (see Table 5).

Table 4. Reasons given for land sales

\begin{tabular}{lcccc}
\hline & \multicolumn{2}{c}{ Giridih } & \multicolumn{2}{c}{ Purulia } \\
\hline & \# of households & $\%$ share & \# of households & $\%$ share \\
Marriage & 36 & $62.1 \%$ & 11 & $50.0 \%$ \\
Medical & 8 & $13.8 \%$ & 5 & $22.7 \%$ \\
Education & 3 & $5.2 \%$ & 0 & $0 \%$ \\
Business & 2 & $3.5 \%$ & 0 & $0 \%$ \\
Land purchase & 1 & $1.7 \%$ & 0 & $0 \%$ \\
Crisis & 5 & $8.6 \%$ & 5 & $22.7 \%$ \\
Livestock purchase & 1 & $1.7 \%$ & 1 & $4.6 \%$ \\
Other reason & 2 & $3.5 \%$ & 0 & $0 \%$ \\
\hline \multicolumn{1}{c}{ Total } & 58 & $100.0 \%$ & 22 & $100.0 \%$ \\
\hline
\end{tabular}

Source: authors' calculation based on the household survey data collected in Giridih and Purulia. See text for details. 
Table 5. Sources of funds reported for land purchases in study area 1997/8 to 2004/6

\begin{tabular}{ccccc}
\hline & \multicolumn{2}{c}{ Giridih } & \multicolumn{2}{c}{ Purulia } \\
\hline & \# of households & \% share & \# of households & $\%$ share \\
\hline crop income & 2 & $2.8 \%$ & 2 & $18.2 \%$ \\
non-agricultural income & 66 & $91.7 \%$ & 9 & $81.8 \%$ \\
Loan & 2 & $2.8 \%$ & 0 & $0 \%$ \\
other & 2 & $2.8 \%$ & 0 & $0 \%$ \\
\hline Total & 72 & $100.0 \%$ & 11 & $100.0 \%$ \\
\hline
\end{tabular}

Source: authors' calculation based on the household survey data collected in Giridih and Purulia. See text for details.

The land rental market appears to have been much less active in our study area during the years covered by the panel survey. The most likely explanation for this is that land owners may be reluctant to enter into rental arrangements out of concern that rental contracts could endanger their ownership rights based on experience from earlier land reform efforts in the study area --which targeted rented land for expropriation.

In summary, the land market appears to be active in both Giridih and Purulia, although both the level of activity and the types of land sales and purchases differed between the two districts. However, there was little reported land rental in either district. In Giridih, where land sales and purchase were more commonly observed in our panel survey, sampled households reported expanded total land holdings, on average. In Purulia, total land sold was greater than the total land purchased. The frequency of land transactions and relatively small land areas involved suggest that the resulting changes in land ownership were demographically driven (need for dowry money) rather than a reflection of any significant trend toward commercialization of agriculture or increased concentration of lands to large land holders. As such, land transactions, by themselves, appear unlikely to alter the local agricultural system or to raise sustainability concerns.

The size of landholdings was positively correlated with the share of total household income accounted for by rice income. Among the landless, marginal, small, medium, and large farmers, the share of total income derived from rice production was $6 \%, 31 \%, 46 \%, 51 \%$, and $60 \%$, respectively, in the baseline survey. Among the smallest landholdiners, the small average share of total gross income derived from rice suggests that efforts to increase rice productivity alone are unlikely to contribute greatly to poverty reduction.

There was wide variation in the share of scheduled tribe (ST) and scheduled caste (SC) families across the sampled villages. However, even in villages with heterogeneous castes, residential segregation according to caste was observed. It is also noteworthy that tolas dominated by ST families tended to occupy more marginal lands, with many farm plots located on unproductive marginal upland. The relationships between a household's caste affiliation or the caste structure of a village and various economic outcomes appear to be complex.

\subsection{Adoption of High Yielding Rice Varieties (HYVs)}

Despite the widely announced accomplishments of the introduction of "Green Revolution" technologies in many parts of India during the 1960s through 1980s, the area covered by our survey has shown very low adoption rates of these technologies. At the time of our baseline survey in the late 1990s, the diffusion of high yielding rice varieties was not widespread in our study area, and based on results from the follow up survey, adoption rates have been particularly low in Giridih villages. The rate of modern rice variety adoption (the share of plots planted with HYVs during the prime post-monsoon growing-- Kharif--season) was only 10 per cent in Giridih and 21 per cent in Purulia districts, according to response in our baseline survey (see Table 6 for full details). (Note 3) Adoption appears to be rising in more recent years, with farms in Purulia increasing their cultivation of HYVs at a much higher rate than farms in Giridih; According to results of our follow up survey, adoption rates increased to 30 per cent and 88 per cent in Giridih and Purulia, respectively. 
Table 6. Adoption of Modern Rice Varieties

\begin{tabular}{ccccccccc}
\hline & \multicolumn{4}{c}{ Giridih } & \multicolumn{3}{c}{ Purulia } \\
\hline & \multicolumn{2}{c}{1997} & \multicolumn{2}{c}{2004} & \multicolumn{2}{c}{1998} & \multicolumn{2}{c}{2006} \\
\hline & \# plots & share & \# plots & share & \# plots & share & \# plots & share \\
\hline Traditional varieties (TV) & 511 & $90.1 \%$ & 512 & $70.4 \%$ & 449 & $79.1 \%$ & 56 & $12.3 \%$ \\
High Yielding Varieties (HYV) & 56 & $9.9 \%$ & 215 & $29.6 \%$ & 119 & $21.0 \%$ & 399 & $87.7 \%$ \\
\hline
\end{tabular}

Source: authors' calculation based on the household survey data collected in Giridih and Purulia. See text for details.

In Purulia, the rate of HYV adoption varied more widely across villages. In 1998, villages with the lowest rate of adoption reported that only 6 per cent of households cultivated HYVs, while nearly half (about 46 per cent) of households reported doing so in the villages with the highest adoption rates. By 2006, all villages surveyed in Purulia reported HYV adoption rates of 80 per cent or higher (the village with the highest adoption rate reported that 97 per cent of households in the village were cultivating HYVs). In contrast, HYV adoption rates among surveyed farms in Giridih villages were more similar across villages in 1997. The village with the highest rate of adoption reported a 27 per cent adoption rate, while the lowest reported a 0 per cent rate. In 2004, adoption rates had increased, ranging between 7 per cent and 60 per cent across villages.

It is clear that HYV adoption proceeded much slower in Giridih than in Purulia, and the adoption rates remained much lower in Giridih (30 per cent) than in Purulia (88 per cent) as of the mid-2000's. Furthermore, among Giridih households cultivating HYVs, a majority reportedly continued to cultivate traditional rice varieties as well, so were only partial adopters of the HYVs. The average share of the plots planted with HYVs among HYV adopting farmers in Giridih was about 54 per cent, while in Purulia the share of partial adopters was only 6 per cent. The 84 per cent share of the surveyed Purulia farmers reportedly adopting HYVs by the time they were interviewed for the follow up survey refers only to the Kharif season rice, and TV's continued to be cultivated at higher rates during seasons with less favourable water availability.

Our study also gathered detailed information on HYV varieties cultivated in Purulia. In 1998, the most popular varieties were: "Swarna" (44 per cent), "Lalat" (18 per cent) and 'Modern' ( 20 per cent) (figures in parentheses indicate the share of plots on which the variety was reportedly cultivatied). Farmers' favor toward the "Swarna" (51 per cent) and "Lalat" (44 per cent) was even clearer by 2007, with a small percentage of farms (4 per cent) using the "Hazar" variety, while other varieties were no longer cultivated in the area.

The observed pattern of HYV adoption (in Purulia) implies that the rapid increase in the HYV adoption rate was not due to the release of newer (and presumably more suitable for the conditions of the area) rice varieties, but rather due to the more recent adoption by farmers of the existing/well-established varieties.

Our data show that benefits of HYV was increasingly adopted in this part of Eastern India, albeit at different rates across Giridih and Purulia, in the late 1990s and early 2000s, more than three decades after the introduction of Green Revolution technologies in Asia. Given the high incidence of poverty and low productivity in agricultural production in the area, this is certainly good news. From sustainability point of view, however, the spread of high-input agriculture typically associated with HYV cultivation in the degraded and ecologically fragile environment is a potential source of concern. In this regard, farmers in Giridih appear to be proceeding rather cautiously; despite the spread of HYV adoption in the late 1990s and early 2000s, the overall adoption rate is still much lower in Giridih than in Purulia, and the majority of them are only partial adopters. Rather ironically, then, farmers in Giridih, who have been much slower adopters of modern rice varieties than their counterparts in Purulia, may arguably be better placed to meeting the challenges of sustainable agriculture in the future.

\subsection{Changes in the Use of Rice Inputs}

In addition to the adoption of high yielding rice varieties, another aspect of rice farming with important implications for sustainability is the amount of inputs used for rice production. Table 7 summarizes results from our surveys, showing that the amount of inputs (per acre) used to produce rice generally increased between 1997/8 - 2004/6. Per acre use of rice seeds increased by 7 per cent across all sample plots, on average ( 5 per cent increase in Giridih and 12 per cent increase in Purulia). Per acre use of FYM increased by almost 40 per cent across all sample plots, on average ( 45 per cent increase in Giridih and 17 per cent increase in Purulia). Per acre use of DAP doubled across all sample plots, on average ( 47 per cent increase in Giridih and 220 per cent increase in Purulia). Per acre use of urea also doubled across all sample plots, on average (105 per cent increase 
in Giridih and 121 per cent increase in Purulia). In contrast, per acre use of SSP decreased by as much as 74 per cent across all sample plots, on average.

Table 7. Changes in the use of rice inputs, per acre Kharif season rice,1997/1998 and 2004/2006)

\begin{tabular}{|c|c|c|c|c|c|c|c|c|c|c|c|c|}
\hline & \multicolumn{6}{|c|}{$1997 / 8$} & \multicolumn{6}{|c|}{$2004 / 6$} \\
\hline & $\begin{array}{l}\text { Giridih \& } \\
\text { Purulia }\end{array}$ & $\begin{array}{c}\text { No. of } \\
\text { plots }\end{array}$ & Giridih & $\begin{array}{c}\text { No. of } \\
\text { plots }\end{array}$ & Purulia & $\begin{array}{c}\text { No. of } \\
\text { plots }\end{array}$ & $\begin{array}{l}\text { Giridih \& } \\
\text { Purulia }\end{array}$ & $\begin{array}{c}\text { No. of } \\
\text { plots }\end{array}$ & Giridih & $\begin{array}{l}\text { No. of } \\
\text { plots }\end{array}$ & Purulia & $\begin{array}{c}\text { No. of } \\
\text { plots }\end{array}$ \\
\hline Seed & 41.89 & 1135 & 42.54 & 567 & 41.24 & 568 & 45.02 & 1584 & 44.47 & 1129 & 46.39 & 455 \\
\hline FYM & 1,022 & 1135 & 1,042 & 567 & 1,002 & 568 & 1,410 & 1584 & 1,507 & 1129 & 1,171 & 455 \\
\hline DAP & 11.00 & 1135 & 13.36 & 567 & 8.66 & 568 & 21.94 & 1584 & 19.59 & 1129 & 27.76 & 455 \\
\hline Urea & 9.66 & 1135 & 9.20 & 567 & 10.11 & 568 & 19.89 & 1584 & 18.89 & 1129 & 22.37 & 455 \\
\hline SSP & 1.03 & 1135 & 0.08 & 567 & 1.98 & 568 & 0.27 & 1129 & 0.265 & 1129 & 0.00 & 0 \\
\hline
\end{tabular}

Source: authors' calculation based on the household survey data collected in Giridih and Purulia. See text for details.

With the increase in HYV adoption during our data period discussed in the prior section, a rapid increase in chemical fertilizer usage is not surprising. However, from the standpoint of the environmental sustainability and economic viability of rice cultivation in the study area, the increased use of chemical-input intensive cultivation is a concern. We note that the increase in organic fertilizer (FYM) was quite a modest pace compared to the increased usage of chemical fertilizer. As observed for other inputs, the increase in organic manure was more pronounced in Giridih than in Purulia.

\subsection{Changes in the Rice Yields}

How has increased adoption of HYVs and application of chemical inputs affected rice yields and rice production in the study area? Results are summarized in Table 8. In Purulia, panel survey results show yields increased between 1998 and 2006. The average yield per acre of traditional rice varieties (TV) increased from 1,004 $\mathrm{kg}$ in 1998 to $1,363 \mathrm{~kg}$ in 2006 (a 36 per cent increase). The average yield per acre of HYV increased from 1,351 kg in 1998 to $1,652 \mathrm{~kg}$ in 2006 (a 22 per cent increase). In contrast, in Giridih, average yields generally stagnated, and in some cases actually declined between 1997 and 2004.The average per acre yield of traditional variety rice in Giridih grew only slightly $(1,097 \mathrm{~kg}$ in 1997 and 1,194kg in 2004) while that of HYV rice declined from 1,584 $\mathrm{kg}$ in 1998 to $1,000 \mathrm{~kg}$ in 2004 (a 37 per cent decline).

In assessing possible influences of the changes in yields observed among surveyed farms, it appears useful to consider the changes in yields suggested by survey results alongside secondary data on rainfall conditions and district level average rice yields (summarized in Table 9). (Note 4) Some of the seemingly contradictory yield trends between the two districts observed in the surveys appear to be explained by yearly differences in weather conditions across the districts and over time. Data suggest 1997 was a "good year" (i.e., a year featuring favorable weather for rice cultivation in Giridih, and relatively high average yields were recorded in the district (1,097 for TV and 1,584 for HYV). In contrast, 1998 was a "bad year" in Purulia and relatively low yields were reported (1,004 for TV and 1,351 for HYV). Detailed data reported from the weather station at Indian Statistical Institute's compound in Giridih indicate that the annual rainfall $(1,485 \mathrm{~mm})$ in 1997 was well above average levels recorded in 1990-2010 (1,199 mm). There was no drought episodes observed in the months of the year corresponding to the critical growth stages of rice. In contrast, weather in Giridih in 2004 was a 'bad year' with low rainfall and a shortened growing season. Total annual rainfall that year $(1,048 \mathrm{~mm})$ was below the historical average $(1,199 \mathrm{~mm})$ and there was an early season drought--little rain was observed in the month of May-that delayed crop establishment. These conditions likely contributed to the yield trend observed between the baseline and follow up surveys in that district. The rice yield reported in 1997 at the experimental farms at the ISI Giridih station) (1.48t/acre) was well above the average during the 1992-2010 period (1.15t/acre), while rice yield in 2004 (1.12 t/acre) was slightly below the Giridih average. 
Table 8. Rice yield (kg/acre) by district, 1997/8-2004/6

\begin{tabular}{|c|c|c|c|c|c|c|c|}
\hline \multicolumn{4}{|c|}{ Giridih } & \multicolumn{4}{|c|}{ Purulia } \\
\hline \multicolumn{2}{|c|}{1997} & \multicolumn{2}{|c|}{2003} & \multicolumn{2}{|c|}{1998} & \multicolumn{2}{|c|}{2005} \\
\hline TV & HYV & TV & HYV & TV & HYV & $\mathrm{TV}$ & HYV \\
\hline $\begin{array}{c}, 097.1 \\
(511)\end{array}$ & $\begin{array}{c}1,584.4 \\
(56)\end{array}$ & $\begin{array}{c}1,197.7 \\
(334)\end{array}$ & $\begin{array}{c}1,000.1 \\
(393)\end{array}$ & $\begin{array}{c}1,003.7 \\
(449)\end{array}$ & $\begin{array}{c}1,350.7 \\
(119)\end{array}$ & $\begin{array}{c}1,363.4 \\
(56)\end{array}$ & $\begin{array}{c}1,651.8 \\
(399)\end{array}$ \\
\hline
\end{tabular}

"number of plots in parentheses

Source: authors' calculation based on the household survey data collected in Giridih and Purulia. See text for details.

Table 9. Secondary Data on Annual Rainfall and Rice Yield by District, 1997/1998-2004/2006

\begin{tabular}{|c|c|c|c|c|}
\hline & \multicolumn{2}{|c|}{ GIRIDIH } & \multicolumn{2}{|c|}{ PURULIA } \\
\hline & data year & historical average & data year & historical average \\
\hline Data year: & \multicolumn{4}{|c|}{ baseline year } \\
\hline Baseline & 1997 & & 1998 & \\
\hline Annual total & $1,485 \mathrm{~mm}^{1}$ & $1,199 \mathrm{~mm}^{1}$ & $1,484 \mathrm{~mm}^{2}$ & $1,341 \mathrm{~mm}^{2}$ \\
\hline Rice yield & $3.65 \mathrm{t} / \mathrm{ha}^{1}$ & $2.85 \mathrm{t} / \mathrm{ha}^{1}$ & $1.47 \mathrm{t} / \mathrm{ha}^{3}$ & $1.91 \mathrm{t} / \mathrm{ha}^{3}$ \\
\hline Data year: & \multicolumn{4}{|c|}{ follow-up year } \\
\hline Follow-up & 2004 & & 2006 & \\
\hline Annual total & $1,048 \mathrm{~mm}^{1}$ & $1,199 \mathrm{~mm}^{1}$ & $1,245 \mathrm{~mm}^{2}$ & $1,341 \mathrm{~mm}^{2}$ \\
\hline Rice yield & $2.77 \mathrm{t} / \mathrm{ha}^{1}$ & $2.85 \mathrm{t} / \mathrm{ha}^{1}$ & $2.61 \mathrm{t} / \mathrm{ha}^{3}$ & $1.91 \mathrm{t} / \mathrm{ha}^{3}$ \\
\hline
\end{tabular}

Detailed data from the meteorological agency in Purulia show that in 1998, while total annual rainfall $(1,484 \mathrm{~mm})$ was slightly above the average over the historical average $(1,341 \mathrm{~mm})$, weekly rainfall data suggest that the onset of monsoon was delayed (i.e., early season drought) in most of the study villages (6 out of 8), which delayed tilling. Poor weather that year also involved intermittent during the flowering stage. (Note 5) However, 2006 was a 'good year,' when relatively high yields were reported in Purulia (1,363 for TV and 1,651 for HYV). In 2006, while the total annual rainfall in Purulia $(1,245 \mathrm{~mm})$ was slightly below the historical average $(1,341 \mathrm{~mm})$, the amount of rainfall in the crucial month of May (at the time of the start of seedbed preparation) was unusually high (not shown in Table 9), which likely contributed to the favourable yield performance in the district in that year. In Purulia in 1998, the average rice yield of $0.59 \mathrm{t}$ /acre (according to reports by the Ministry of Agriculture) was well below the average during the reported data period of 1991-2007 (0.77 t/acre) while the rice yield in 2006 (1.06 t/acre) was above average. (Note 6)

In addition, our data also suggest that, in line with the popular perception, yields tend to be more stable (1,004 $1,363 \mathrm{~kg} / \mathrm{acre}$ ) and less vulnerable to bad weather conditions among TVs while HYV yields tend to fluctuate more widely $(1,000 \sim 1,584 \mathrm{~kg} / \mathrm{acre})$ and HYVs are possibly more vulnerable to negative weather shocks.

Our yield data show there was a positive trend in yields for both traditional and modern rice varieties in Purulia and this trend was consistent with the rainfall information obtained from secondary source data on district level yields. While in Giridih, rice yields were largely stagnant between 1997 and 2004 (despite notable increases in the use of chemical inputs - especially fertilizer - as noted in the previous section) with rainfall seeming to contribute to this trend. (Note 7) The increased use of chemical fertilizers alongside the falling yields suggests a disturbing possibility that farmers in Giridih have applied increasing amounts of fertilizer in the effort to maintain rice yields while cultivating rice on plots that suffer depletion of soil nutrients over time due to continuous and intensive rice cultivation. This raises a serious concern from sustainability point of view in the area under study. 


\section{Conclusions}

This paper analysed longitudinal household surveys collected in two adjacent districts on the Chhotanagpur Plateau in Eastern India during the period between 1997 and 2006 to assess yield changes and changes in agricultural inputs and their impacts on the sustainability of local agricultural systems. The study area is a poverty stricken and environmentally fragile part of Eastern India with a significant proportion of residents from scheduled tribes. Examining the changes in the landholding patterns (i.e., land market transactions), use of HYV and of other inputs (mainly fertilizer) in rice cultivation and the changes in rice yields, the study contributes to the limited empirical understanding about the evolution of agricultural systems in impoverished rain fed areas of Eastern India.

Our data show that despite the relatively unfavourable natural resource endowments and the relative lack of economic opportunities, few farming households were observed out migrating during our observation period in the both districts. The fact that the total number of households increased by one quarter suggests the area is facing mounting population pressure likely to place additional burden on the already fragile land endowment.

The benefits of the green revolution, over 30 years after its onset in Asia, appear to have finally reached this poverty stricken and low productivity part of Eastern India. In Purulia, yields for both TVs and HYVs increased between the baseline and the follow-up surveys. In contrast, in Giridih, yields from TV held steady, while HYV yields actually declined for reasons traced to changes in growing conditions across these years.

The trends observed in the rice cultivation practices and outcomes in our study area provide both positive and negative implications for the sustainability of local livelihoods--and particularly of the rice-centred agricultural system. The stability of ownership and landholding is encouraging in terms of prospects for the small landholding households covered in our panel survey continuing to be able to derive their farm-based livelihoods. However, the mixed results from increased cultivation of HYVs raise sustainability concerns in Giridih.

Nonetheless, the research suggests the latent sustainability of the agricultural system may actually be greater in Giridih. Despite the more 'progressive' local governance in Purulia, where the Panchayat system is better developed, land reform was more actively and completely implemented in the past, and HYV adoption rate was faster and appeared more sound technically; in Giridih, the total land available for our sample farmers increased as the result of land market transactions. Farmers in Giridih have been more cautious in their move toward high-chemical intensity agriculture favouring, instead, increased use of organic manure more rapidly (although at a much slower pace than their increase in chemical usage).

Overall, given the high rate of poverty and the unfavourable and degraded natural resource base in the Chhotanagpur Plateau in general, farmers in the both districts imply small landholding farms in both Giridih and Purulia may face a rising challenges in terms of maintaining their livelihoods in the future.

As we discussed in the introduction, the area studied by this paper has been identified as a poverty stricken area based on secondary data and on our earlier studies. We have highlighted the impact of household socioeconomic characteristics in shaping the outcomes with respect to the sustainability of the agircultual system in the study area, however, further efforts to assemble information to disucss these issues (i.e., changes in the level of household welfare over time as measured by changes in consumption expenditure) are needed and is planned in future extension of the research. Also, we have attempted to identify potential welfare implications of future yield changes (i.e., income losses and rising poverty) qualitatively in this paper, but addressing these questions more rigorously is saved for a future paper.

\section{Acknowledgments}

The input and support of Mahabub Hossain and Suan Pheng Kam in the early phase of this research, and excellent research assistance by Melba Tutor and Lorena Villano are gratefully acknowledged.

\section{References}

Ballabh, V., \& Pandey, S. (1999). Transitions in rice production systems in eastern India: Evidence from two villages in Uttar Pradesh. Economic and Political Weekly, 34(13), A11-A16.

Banik, P., Edmonds, C. M., Fuwa, N., Kam, S. P., Villano, L., \& Bagchi, D. K. (2004). Natual resource endowments, subsistence agriculture, and rural poverty in Chhotanagpur Plateau. International Rice Research Institute Discussion Paper No. 47. Los Baños: International Rice Research Institute.

Buggi, C. (1987). Some aspects of structural transformation in Indian rural society. Bangalore: India: Department of Rural Sociology, University of Agricultural Sciences (unpublished).

Deaton A. (2001). Computing prices and poverty rates in India, 1999-2000. Draft. Research Program in 
Development Studies, Princeton University, Princeton, N.J. (USA).

Fuwa, N., Edmonds, C. M., \& Banik, P. (2007). Are small-scale rice farmers in eastern India really inefficient? Examining the effects of microtopography technical efficiency estimates. Agricultural Economics, 36, 335-346. http://dx.doi.org/10.1111/j.1574-0862.2007.00211.x

Ghosh, B. K. (2010). Fading glory of West Bengal agriculture in the context of globalization: Need for a change in cropping pattern. Trends in Agricultural Economics, 3(4), $185-189$. http://dx.doi.org/10.3923/tae.2010.185.189

Janaiah, A., Hossain, M., \& Otsuka, K. (2006). Productivity impact of the modern varieties of rice in India. The Developing Economies, 44(2), 190-207. http://dx.doi.org/10.1111/j.1746-1049.2006.00013.x

Kemmeyer, K. C., Ritzer, G., \& Yetman, N. R. (1994). Sociology: Experiencing changing societies. Boston: Allyn and Bacon.

Kumar, P., \& Mittal, S. (2006). Agricultural productivity trends in India: Sustainability issues. Agricultural Economics Research Review, 19(Conference No.), 71-88.

Kumar, S., \& Chand, R. (2012). Land use dynamics and cropping pattern: Case study of village in Karnal District of Haryana. Agricultural Science Digest, 32(1), 83-86.

Sharma, D., \& Shardendu, S. (2011). Assessing farm-level agricultural sustainability over a 60-year period in rural eastern India. Environmentalist, 31(3), 325-337. http://dx.doi.org/10.1007/s10669-011-9341-x

Singh, R. B. (2000). Environmental consequences of agricultural development: a case study from the Green Revolution state of Haryana, India. Agriculture. Ecosystems and Environment, 82, 97-103. http://dx.doi.org/10.1016/S0167-8809(00)00219-X

Venkateswarlu, B., \& Prasad, J. V. N. S. (2012). Carrying capacity of Indian agriculture: issues related to rain-fed agriculture. Current Science, 102(6), 882-887.

\section{Notes}

Note 1. The state of Jharkhand was formed in 2000 and includes one of the two districts that make up the study area for this research. When the initial phase of fieldwork for this study was completed, Giridih District was a part of Bihar State.

Note 2. In the follow up survey, households were surveyed if they traced their original back to one of the households covered in the baseline survey. Many of the households experienced the departure of members between the baseline and follow up surveys, in which cases, the follow up survey covered both the original household and any new households formed from the original household residing in the same village (e.g., child married and formed new household).

Note 3. Due to the underdevelopment of irrigation facilities in the area, rice cultivation is largely concentrated in the Kharif (monsoon) season. Thus, we will focus on kharif season production for this and subsequent discussions.

Note 4. The secondary data on both rainfall and rice yield for Giridih reported in Table 9 are obtained from Indian Statistical Institute (ISI)'s Giridih Office. We use time series data on rainfall (recorded at the weather station in the ISI Giridih premise) as well as on rice yield (based on the yearly yield of IET1444 variety, a high yielding variety) grown on ISI's experimental plots located in Giridih town), which we consider as the most reliable time series data available for Giridih district. Since similar data are not available in the case of Purulia, however, the Purulia data series reported in Table 9 are based on the official rainfall data obtained from the metrological agency in Purulia and on the annual rice yield data reported by the Directorate of Rice Development, Ministry of Agriculture.

Note 5. While the normal timing of the onset of monsoon is $23 \mathrm{rd}$ week, monsoon started 4 weeks after the normal in six out of the 8 villages in Purulia.

Note 6. Since the data sources between Giridih and Purulia are different, the level of yield is not directly comparable between the two districts.

Note 7. This pattern is also consistent with the secondary data reported by the Ministry of Agriculture. During the period 1991-2007, there was a positive and statistically significant time trend in rice yield in Purulia, but the time trend in rice yield in Giridih is not statistically significantly different from zero. 


\section{Copyrights}

Copyright for this article is retained by the author(s), with first publication rights granted to the journal.

This is an open-access article distributed under the terms and conditions of the Creative Commons Attribution license (http://creativecommons.org/licenses/by/3.0/). 